\title{
THE ROLE OF ORGANIZATIONAL COMMITMENTS IN MEDIATING THE EFFECT OF WORKPLACE BULLYING ON EMPLOYEE TURNOVER INTENTIONS
}

\author{
I Nyoman Andika Indrananta and I Wayan Gede Supartha \\ Faculty of Economics and Business, Udayana University, Bali, Indonesia
}

http://doi.org/10.35409/IJBMER.2021.3270

\begin{abstract}
This study aims to analyze the effect of workplace bullying and organizational commitment on employee turnover intention, as well as to analyze the mediating role of organizational commitment variables. This research was conducted in BPR Naga Sukawati, Gianyar. Testing the research hypothesis using Structural Equation Modeling (SEM) analysis techniques using SMARTPLS assistance, using IBM SPSS Statistics 22 to test the validity and reliability, the population in this study was 54 respondents, the research sample was taken using saturated sample determination techniques, with the criteria of employee respondents PT. BPR Naga Sukawati-Gianyar. The results showed that (1) workplace bullying has a positive and significant effect on employee turnover intention, (2) workplace bullying has a negative and significant effect on employee organizational commitment, (3) organizational commitment has a negative and significant effect on employee turnover intention, (4) commitment organization mediated the effect of workplace bullying on employee turnover intention. The managerial implications and suggestions in this study are to reduce the turnover intention rate of employees, companies or institutions to minimize the level of workplace bullying that occurs in the company and increase employee organizational commitment. With the low level of workplace bullying that occurs in the company, it will increase organizational commitment, and reduce employee intentions to resign.
\end{abstract}

Keyword: workplace bullying, organizational commitment, turnover intention.

\section{INTRODUCTION}

Employees are one of the main assets or assets for the company which are the determinants of the company's success or failure. To get selected employees, the company carries out a series of well-integrated HR management steps. One of the goals of HR management is so that selected employees can work, contribute, and last a long time.

The company always strives to make employees work for a long time at the company, so that the employee turnover rate is at a relatively low level. Employee turnover, although not always a bad connotation, will affect the smooth running of the company's operations. Thus, a controlled turnover rate is one of the goals of HR management. High employee turnover has negative impacts, including decreased sales figures, reduced customer satisfaction, large recruitment and training costs, and loss of productive work time. If left in the long run, this condition is a bad indication and can affect company performance. The negative impact of turnover is the impact 


\section{International Journal of Business Management and Economic Review}

Vol. 4, No. 03; 2021

ISSN: 2581-4664

on organizational costs related to the recruitment, selection and training of new personnel, plus turnover can cause a decrease in the effectiveness and productivity of employee performance because they have lost their co-workers (Jha, 2010).

Employee turnover is a permanent employee resignation, either voluntary (voluntary) or involuntary (involuntary) in a company (Robbins and Judge, 2015: 38). Abdillah (2012) states that turnover intention is a condition in which employees have the desire or intention to find another job at a different company as an alternative. Turnover intention can also be said to be the movement of employees to leave the company to get a new job at another company. The negative impact of turnover is the company costs associated with recruiting, selecting and training new personnel. In addition, turnover can also cause a decrease in the effectiveness and productivity of employee performance because they have lost their co-workers (Jha, 2010).

According to Bohle et al. (2017), one of the things that greatly affects employee turnover intention is workplace bullying. Yuksel and Tuncsiper (2011) state that there is a positive relationship between mobbing (bullying) at work and the intention to quit (intention to quit). Coetzee and Dyk (2017) state that the high level of bullying in the workplace affects the high turnover intention. Hernandez et al. (2018) stated that exposure to workplace bullying may lead employees to consider leaving their jobs as a form of treatment. Glambek et al. (2014) in their findings show that employees who are bullied, their job requirements and content are not safe, and they may be at risk of making a turnover and leaving the workplace.

Bullying is a repetitive negative behavior that is intended to cause displeasure or pain by others, either one or several people directly towards someone who is unable to fight it (Olweus, 2006). Rigby (2002: 15) defines bullying as repetitive suppression or bullying, psychologically or physically against someone who has less power or power by a stronger person or group of people.

Workplace bullying is an issue in the world of work that now attracts many people. The issue of workplace bullying is recognized by the International Labor Organization (ILO) as an international occupational health and safety issue. The ILO notes that physical and emotional violence will be one of the most serious problems faced in the workplace in the new millennium. This shows that the issue of work bullying has received serious attention from the international community. Although other types of violence are receiving more media attention, workplace bullying is increasingly the focus of researchers, employers, trade unions, occupational health and safety professionals.

Hoel and Cooper (2000) say that no company is immune from bullying, although the scale and intensity of the problem varies greatly between companies. this indicates that, every company must be aware that workplace bullying may occur within the company. Therefore, every company must be aware of it. Einarsen et al .. (2003) stated that victims of bullying have consequences such as mental stress and mental health problems. In addition, bullying is detrimental to the company because the company will experience high employee turnover, high absenteeism and decreased organizational commitment and employee productivity. Another disadvantage of bullying is the time and money spent investigating the absence of employees who experience bullying and employees who witness it are more likely to leave the company, high recruitment costs due to high employee turnover rates, including court fees (in case of abuse) and fees. -Other costs.

Hoel and Cooper (2000) stated that bullying can only develop, if it continues to be allowed and 


\section{International Journal of Business Management and Economic Review}

Vol. 4, No. 03; 2021

ISSN: 2581-4664

there is no direct or indirect action by management. If it continues, then actions that tolerate bullying will result in employee turnover, particularly turnover intention. According to Hoel and Cooper (2000), all companies have policies and procedures that can handle problems when bullying occurs and can act as a barrier for bullying to develop in the future. To develop a work environment free of bullying, management must examine HRM practices that can contribute directly or indirectly to bullying.

According to Djamilah et al. (2012), so that victims of bullying avoid bullying, usually they will have a high desire to leave which results in a real turnover. Thus, it can be said that bullying has a direct impact on the desire to leave. But besides that, bullying can occur using other mechanisms, namely through a decrease in affective organizational commitment for victims of bullying which in turn will result in a desire to leave the company.

Rodly (2012) states that there are many factors that cause employees to move from their workplace, but the determinant factor of willingness to move includes organizational commitment. Organizational commitment is the level to which an employee sides with a company and their goals and desires to maintain membership in the company (Robbins, 2015: 100). According to Miner (1992) when employees have high organizational commitment, it will strengthen the determination of an employee not to leave the company, even though other companies support him to leave.

Labrague et al. (2018) stated that organizational commitment has a negative and significant effect on the desire to leave. Luz et al. (2018) stated that affective and normative commitment have a negative and significant effect on turnover intention. Dumitru et al. (2015) confirmed the negative relationship between organizational commitment and intention to leave the company. The same is true with the relationship between affective organizational commitment and intention to leave the company, and between normative organizational commitment and intention to leave the company. In line with the results of research conducted by Bhatti et al. (2016) and Jehanzeb et al. (2013) which states that organizational commitment has a negative and significant effect on turnover intention.

Different results were found by Park et al. (2014) who show that statistically union organizational commitment has no significant effect on turnover intention at the conventional significance level. Kaushalya and Alwis (2016) also stated that organizational commitment did not have a significant effect on the desire to leave. Likewise, the results of research conducted by Tnay et al. (2013) found that organizational commitment was not significantly related to turnover intention.

Malik et al. (2018) stated that workplace bullying has a negative relationship with organizational commitment. McCormack et al. (2009) in their findings show that there is a negative and significant direct effect of bullying on the affective commitment. Dumitru et al. (2015) stated that there is a positive relationship between continuance organizational commitment and bullying in the workplace. Different results were found by Yuksel and Tuncsiper (2011), where in their research there was no evidence of a significant relationship between mobbing (bullying) and organizational commitment, as well as between mobbing (bullying) and normative commitment. However, in his research, it is proven that there is a significant negative relationship between mobbing (bullying) and affective commitment. increase in employee affective commitment will lead to decreased intention to quit and continuance commitment. 
International Journal of Business Management and Economic Review

Vol. 4, No. 03; 2021

ISSN: 2581-4664

\section{LITERATURE REVIEW AND HYPOTHESIS DEVELOPMENT}

Yuksel and Tuncsiper (2011) state that there is a positive relationship between mobbing (bullying) at work and the intention to quit (intention to quit). Coetzee and Dyk (2017) state that the high level of bullying in the workplace affects the high turnover intention. Hernandez et al. (2018) stated that exposure to workplace bullying may lead employees to consider leaving their jobs as a form of treatment. Glambek et al. (2014) in their findings show that employees who are bullied, their job requirements and content are not safe, and they may be at risk of making a turnover and leaving the workplace. Rasool et al. (2013) stated workplace bullying had a positive impact on intention to leave. Razzaghian and Ghani (2014), Mete and Sokmen (2016), as well as Coetzee and Oosthuizen (2017) state a significant positive relationship between bullying at work and the intention to quit. The same thing was stated by Kaushalya and Alwis (2016), Malik et al. (2018), Nwobia and Aljohani (2017), Dumitru et al. (2015), Salin and Notelaers (2017), and Park et al. (2018) who state that workplace bullying has a positive and significant effect on turnover intention.

H1: Workplace bullying has a positive and significant effect on turnover intention.

Malik et al. (2018) stated that workplace bullying has a negative relationship with organizational commitment. McCormack et al. (2009) in their findings show that there is a negative and significant direct effect of bullying on the affective commitment. Dumitru et al. (2015) stated that there is a positive relationship between continuance organizational commitment and bullying in the workplace.

Different results were found by Yuksel and Tuncsiper (2011), where in their research there was no evidence of a significant relationship between mobbing (bullying) and organizational commitment, as well as between mobbing (bullying) and normative commitment. However, in his research, it is proven that there is a significant negative relationship between mobbing (bullying) and affective commitment. increase in employee affective commitment will lead to decreased intention to quit and continuance commitment.

$\mathrm{H} 2$ : Workplace bullying has a negative and significant effect on organizational commitment.

Labrague et al. (2018) stated that organizational commitment has a negative and significant effect on the desire to leave. Luz et al. (2018) stated that affective and normative commitment have a negative and significant effect on turnover intention. Dumitru et al. (2015) confirmed the negative relationship between organizational commitment and intention to leave the organization. The same is the case with the relationship between affective organizational commitment and intention to leave the organization, as well as between normative organizational commitment and intention to leave the organization. In line with the results of research conducted by Bhatti et al. (2016) and Jehanzeb et al. (2013) which states that organizational commitment has a negative and significant effect on turnover intention. Ghosh et al. (2013), Cho and Huang (2012) and Sartika (2014) in their research indicate that the higher the organizational commitment, the lower the desire to leave.

Different results were found by Park et al. (2014) who show that statistically union organizational commitment has no significant effect on turnover intention at the conventional significance level. Kaushalya and Alwis (2016) also stated that organizational commitment did not have a significant effect on the desire to leave. 


\section{International Journal of Business Management and Economic Review}

Vol. 4, No. 03; 2021

ISSN: 2581-4664

H3: Organizational commitment has a negative and significant effect on turnover intentions.

McCormack et al. (2009) proved that affective commitment partially mediates the relationship between bullying and the desire to leave. Djamilah et al. (2012), state that jointly and partially workplace bullying and affective organizational commitment have a significant effect on desire to leave. Therefore, the company should prevent the emergence of workplace bullying behavior, for example making ethical standards of work behavior. Rasool et al. (2013), stated that workplace bullying is more relevant to systematic weakness in the organization and less to employee performance while workplace bullying is more related to the personal characteristics of the victim, so regardless of their commitment, leaving the organization in such circumstances is a better alternative to victim.

H4: Organizational commitment mediates the effect of workplace bullying on turnover intentions.

\section{RESEARCH METHODS}

This study uses an explanatory research approach, which explains a relationship between variables through hypothesis testing. This study was conducted to explain the effect of workplace bullying on employee turnover intention, with organizational commitment as the mediator. This research was conducted at PT BPR NAGA. The population in this study were employees at PT BPR Naga whose number can be counted with certainty (finite) as many as 54 people. The sampling method used in this study was saturated samples. The sample in this study were all employees who worked at PT BPR Naga Sukawati-Gianyar, as many as 54 people. The technique used in this study is the Partial Least Square (PLS) analysis technique.

\section{RESULTS AND DISCUSSION} Results of Inferential Analysis (PLS)

In this study, inferential data analysis used the Partial Least Square (PLS) approach. PLS is a multivariate statistical technique that makes comparisons between multiple dependent variables and multiple independent variables. PLS is a variant-based SEM statistical method designed to solve multiple regression when specific data problems occur, such as sample size and missing data and multicollinearity. PLS is a powerful analytical method because it is not based on many assumptions. The data do not have to be normally distributed multivariate (indicators with a catagorial scale, ordinal, until the ratio can be used in the same model), the sample does not have to be large. Although PLS can also be used to confirm a theory, it can also be used to explain whether or not there is a relationship in latent variables.

\section{Evaluation Result of Measurement Model (Outer model)}

The evaluation of the outer model is also called the evaluation of the measurement model to assess the validity and reliability of the model. Analysis of the construct measurement model with indicator reflection wants to see the validity of each indicator and test the reliability of the construct. The criterion for indicator validity is measured by convergent validity, while construct reliability is measured by composite reliability and average variance extracted or AVE.

1) Convergent Validity

Convergent validity, namely the correlation between the score for the reflexive indicator and the score for the latent variable. This study uses a loading of 0.5 to 0.6 which is considered 


\section{International Journal of Business Management and Economic Review}

Vol. 4, No. 03; 2021

ISSN: $2581-4664$

sufficient, because it is the initial stage of developing a measurement scale and the number of indicators per variable is not large, ranging from three to eight indicators.

Based on Table 1, it can be seen that all values in the convergent validity test are greater than 0.6. Thus it can be stated that the data in the study are valid.

Table 1. Convergent Validity Test Results

\begin{tabular}{|c|c|c|c|}
\hline & Organizational Commitment & Turnover Intentions & Workplace Bullying \\
\hline X.1 & & & 0.761 \\
\hline X.2 & & & 0.854 \\
\hline X.3 & & & 0.859 \\
\hline X.4 & & & 0.831 \\
\hline X.5 & & & 0.855 \\
\hline X.6 & & & 0.918 \\
\hline $\mathbf{X . 7}$ & & & 0.916 \\
\hline X.8 & & & 0.835 \\
\hline Y1.1 & 0.918 & & \\
\hline Y1.2 & 0.979 & & \\
\hline Y1.3 & 0.965 & & \\
\hline Y2.1 & & 0.762 & \\
\hline Y2.2 & & 0.808 & \\
\hline Y2.3 & & 0.792 & \\
\hline Y2.4 & & 0.795 & \\
\hline Y2.5 & & 0.783 & \\
\hline
\end{tabular}

Primary Data, 2021

2) Discriminate validity

To assess discriminant validity is the square root of average variance extracted (AVE) for each variable with a correlation between other variables in the model. If the initial measurement value of the two methods is better than the values of the other variables in the model, it can be concluded that this variable has good discriminant validity or vice versa. Accordingly, it is recommended that the measurement value be more than 0.50 .

Table 2. AVE Test Results

\begin{tabular}{|ll|}
\hline & Average Variance Extracted (AVE) \\
\hline Organizational Commitment & 0.911 \\
\hline Turnover Intentions & 0.621 \\
\hline Workplace Bullying & 0.731 \\
\hline
\end{tabular}

Primary Data, 2021

Based on the table above, it can be seen that all AVE values are greater than 0.5. Thus it can be 


\section{International Journal of Business Management and Economic Review}

Vol. 4, No. 03; 2021

ISSN: 2581-4664

stated that the data in the study are valid.

3) Composite Reliability

Composite reliability is a group of indicators that measure a variable having good composite reliability, Composite Reliability measures internal consistency and the value must be above 0.70 .

Table 3. Reliability Test Results Composite reliability

\begin{tabular}{|ll|}
\hline & Composite Reliability \\
\hline Organizational Commitment & 0.968 \\
\hline Turnover Intentions & 0.891 \\
\hline Workplace Bullying & 0.956 \\
\hline
\end{tabular}

Primary Data, 2021

Based on the table above, it can be seen that all the composite reliability values on each variable are greater than 0.7 . Thus it can be stated that the data in the study are reliable.

\section{Result of Structural Model Evaluation (Inner model)}

In assessing the structural model with the PLS structural, it can be seen from the Q-squares value for each endogenous latent variable as the predictive strength of the structural model. The value of R-squares is a goodness fit model test. However, if the calculation results show that the Qsquare value is more than 0 (zero), then the model deserves to be said to have a relevant predictive value. Calculation of $Q$-square through the formula $Q^{2}=1-\left[\left(1-R_{1}{ }^{2}\right)\left(1-R_{2}{ }^{2}\right)\right]$ so it requires an R-square value which also functions to find out how much the contribution of variable $\mathrm{X}$ to $\mathrm{Y}$.

1) R - square

The R-square value can be used to evaluate the effect of predictors on each endogenous latent variable. R2 results of $0.67,0.33$, and 0.19 for endogenous latent variables in the structural model indicate that the model is "good", "moderate", and "weak". The R-square value is used to later calculate the Q-square value which is a test of the goodness of fit model.

Table 4. R-square test results

\begin{tabular}{|c|c|c|}
\hline & R Square & R Square Adjusted \\
\hline Organizational Commitment & 0.248 & 0.234 \\
\hline Turnover Intentions & 0.778 & 0.769 \\
\hline
\end{tabular}

Primary Data, 2021

Based on the table above, the R-square value for the Workplace bullying variable on organizational commitment is 0.248 including weak, which indicates that it has a large influence 


\section{International Journal of Business Management and Economic Review}

Vol. 4, No. 03; 2021

ISSN: 2581-4664

of $0.248 \times 100 \%=24.8 \%$. The R-square value for the Workplace bullying variable on Turnover Intention of 0.778 is considered good, which shows that it has a large influence of $0.778 \times 100 \%$ $=77.8 \%$.

2) $\mathrm{Q}$ - square

Inner model testing is done by looking at the Q-square value which is a test of the goodness of fit model. If the Q-square value is greater than 0 (zero), it shows that the model has a predictive relevance value, while the Q-square value is less than 0 (zero), it shows that the model has less predictive relevance. The Q-square calculation can be seen as follows:

$\mathrm{Q}^{2}=1-\left[\left(1-\mathrm{R}_{1}^{2}\right)\left(1-\mathrm{R}_{2}^{2}\right)\right]$

$\mathrm{Q}^{2}=1-[(1-0,248)(1-0,778)]$

$\mathrm{Q}^{2}=1-[(0,752)(0,222)]$

$\mathrm{Q}^{2}=1-(0,1669)$

$\mathrm{Q}^{2}=0,8331$

Based on the above calculations, the Q-square value of 0.833 is more than 0 and close to 1 , so it can be concluded that the model has a predictive value or indicates that the structural model designed to explain organizational commitment and turnover intention at PT BPR NAGA is proven to be good or relevant.

Hypothesis test

In testing the hypothesis it can be seen from the t-statistic value and the probability value. For alpha $5 \%$, the exogenous variable is significant to the endogenous variable if the $t$-statistic is $>$ 1.96 , and if the $p$ value is $<0.05$.

Table 5. Direct Effect Test Results

\begin{tabular}{|lllllll|}
\hline & & $\begin{array}{l}\text { Original } \\
\text { Sample } \\
(\mathbf{O})\end{array}$ & $\begin{array}{l}\text { Sample } \\
\text { Mean } \\
(\mathbf{M})\end{array}$ & $\begin{array}{l}\text { Standard } \\
\text { Deviation } \\
(\text { STDEV })\end{array}$ & $\begin{array}{l}\text { T Statistics } \\
(\mid \mathbf{O} / \text { STDEV } \mid\end{array}$ & $\begin{array}{l}\text { P } \\
\text { Val } \\
\text { ues }\end{array}$ \\
\hline $\begin{array}{l}\text { Workplace Bullying } \\
\text { Turnover Intentions }\end{array}$ & $->$ & 0.306 & 0.302 & 0.098 & 3.112 & $\begin{array}{l}\mathbf{0 . 0 0} \\
\mathbf{2}\end{array}$ \\
\hline $\begin{array}{l}\text { Workplace Bullying } \\
\text { Organizational } \\
\text { Commitment }\end{array}$ & $->$ & -0.498 & -0.51 & 0.112 & 4.443 & $\begin{array}{l}\mathbf{0 . 0 0} \\
\mathbf{0}\end{array}$ \\
\hline $\begin{array}{l}\text { Organizational } \\
\text { Commitment-> Turnover } \\
\text { Intentions }\end{array}$ & -0.688 & -0.696 & 0.076 & 9.07 & $\mathbf{0 . 0 0}$ \\
\hline
\end{tabular}

Primary Data, 2021

Based on the table above, the p-value and t-statistics for each variable are obtained, which are explained as follows.

(1) The p-value of the workplace bullying variable on turnover intention is 0.002 and the tstatistic value is 3.112 . Because the p-value $<0.05(0.002<0.05)$ with a positive beta value of 0.306 , and a t-statistic value $>1.96(3,112>1.96)$, it can be concluded that 


\section{International Journal of Business Management and Economic Review}

Vol. 4, No. 03; 2021

ISSN: 2581-4664

workplace bullying has a significant positive effect on workplace bullying. turnover intention, this means that the first hypothesis (H1) is accepted.

(2) The p-value of the workplace bullying variable on organizational commitment is 0,000 and the t-statistic value is 4.443 . Because the p-value $<0.05(0.000<0.05)$ with a beta value of negative (-) 0.498 , and the t-statistic value $>1.96$ (4.443> 1.96), it can be concluded that workplace bullying has an effect. significant negative towards organizational commitment, this means that the second hypothesis $(\mathrm{H} 2)$ is accepted.

(3) The p-value of the variable organizational commitment to turnover intention is 0,000 and the t-statistic value is 9,070 . Because the p-value $<0.05(0.000<0.05)$ with a beta value of negative (-) 0.688 , and the t-statistic value $>1.96(9,070>1.96)$, it can be concluded that organizational commitment has an effect. significant negative towards turnover intention, this means that the third hypothesis (H3) is accepted.

Table 6. Indirect Effect Test Results

\begin{tabular}{|c|c|c|c|c|c|c|}
\hline & & $\begin{array}{l}\text { Original } \\
\text { Sample } \\
\text { (O) }\end{array}$ & $\begin{array}{l}\text { Sample } \\
\text { Mean } \\
\text { (M) }\end{array}$ & $\begin{array}{l}\text { Standard } \\
\text { Deviation } \\
\text { (STDEV) }\end{array}$ & $\begin{array}{l}\text { T Statistics } \\
\text { (|O/STDE } \\
\text { V|) }\end{array}$ & $\begin{array}{l}\text { P } \\
\text { Val } \\
\text { ues }\end{array}$ \\
\hline $\begin{array}{l}\text { Workplace Bullying } \\
\text { Organizational Commitment } \\
\text { Turnover Intentions }\end{array}$ & $\begin{array}{l}\Rightarrow> \\
\Rightarrow>\end{array}$ & 0.343 & 0.356 & 0.093 & 3.685 & $\begin{array}{l}\text { 0.0 } \\
00\end{array}$ \\
\hline
\end{tabular}

Primary Data, 2021

(4) The p-value of the workplace bullying variable on turnover intention through organizational commitment is 0,000 and the t-statistic value is 3.685 . Because the pvalue $<0.05(0.000<0.05)$ with a beta value of positive 0.334 , and the t-statistic value $>$ 1.96 (3.685> 1.96), it can be concluded that organizational commitment is able to mediate the effect. workplace bullying on turnover intention, this means that the fourth hypothesis (H4) is accepted.

\section{The Effect of Workplace Bullying on Turnover Intention}

The results of hypothesis testing indicate that workplace bullying has a positive and significant effect on turnover intention. These results can illustrate that the lower the workplace bullying experienced by employees, the lower the intention to leave (turnover intention). On the other hand, the higher the workplace bullying experienced by employees, the higher the intention to leave (turnover intention).

Yuksel and Tuncsiper (2011) state that there is a positive relationship between mobbing (bullying) at work and the intention to quit (intention to quit). Coetzee and Dyk (2017) state that the high level of bullying in the workplace affects the high turnover intention. Hernandez et al. (2018) stated that exposure to workplace bullying may lead employees to consider leaving their jobs as a form of treatment. Glambek et al. (2014) in their findings show that employees who are bullied, their job requirements and content are not safe, and they may be at risk of making a 


\section{International Journal of Business Management and Economic Review}

Vol. 4, No. 03; 2021

ISSN: 2581-4664

turnover and leaving the workplace. Rasool et al. (2013) stated workplace bullying had a positive impact on intention to leave. Razzaghian and Ghani (2014), Mete and Sokmen (2016), as well as Coetzee and Oosthuizen (2017) state a significant positive relationship between bullying at work and the intention to quit. The same thing was stated by Kaushalya and Alwis (2016), Malik et al. (2018), Nwobia and Aljohani (2017), Dumitru et al. (2015), Salin and Notelaers (2017), and Park et al. (2018) who state that workplace bullying has a positive and significant effect on turnover intention.

\section{The Effect of Workplace Bullying on Organizational Commitment}

The results of hypothesis testing indicate that workplace bullying has a negative and significant effect on organizational commitment. These results can illustrate that the lower the workplace bullying experienced by employees, the higher the level of employee organizational commitment. Conversely, the higher the workplace bullying experienced by employees, the lower the level of employee organizational commitment.

Malik et al. (2018) stated that workplace bullying has a negative relationship with organizational commitment. McCormack et al. (2009) in their findings show that there is a negative and significant direct effect of bullying on the affective commitment. Dumitru et al. (2015) stated that there is a positive relationship between continuance organizational commitment and bullying in the workplace.

\section{The Effect of Organizational Commitment on Turnover Intention}

The results of hypothesis testing indicate that organizational commitment has a negative and significant effect on turnover intention. These results can illustrate that the lower the level of employee organizational commitment, the higher the employee's intention to leave (turnover intention). Conversely, the higher the level of employee organizational commitment, the lower the intention to leave (turnover intention).

Labrague et al. (2018) stated that organizational commitment has a negative and significant effect on the desire to leave. Luz et al. (2018) stated that affective and normative commitment have a negative and significant effect on turnover intention. Dumitru et al. (2015) confirmed the negative relationship between organizational commitment and intention to leave the organization. The same is the case with the relationship between affective organizational commitment and intention to leave the organization, as well as between normative organizational commitment and intention to leave the organization. In line with the results of research conducted by Bhatti et al. (2016) and Jehanzeb et al. (2013) which states that organizational commitment has a negative and significant effect on turnover intention. Ghosh et al. (2013), Cho and Huang (2012) and Satika (2014) in their research indicate that the higher the organizational commitment, the lower the desire to leave. 


\section{International Journal of Business Management and Economic Review}

Vol. 4, No. 03; 2021

ISSN: 2581-4664

The Effect of Workplace Bullying on Turnover Intention through Organizational Commitment The results of hypothesis testing indicate that workplace bullying has a significant positive effect on turnover intention through organizational commitment. The results of the mediation effect test carried out by examining the coefficient of direct influence of exogenous variables on endogenous variables in the model involving the mediating variable showed that organizational commitment as partial mediation on the effect of workplace bullying on turnover intention.

McCormack et al. (2009) proved that affective commitment partially mediates the relationship between bullying and the desire to leave. Djamilah et al. (2012), state that jointly and partially workplace bullying and affective organizational commitment have a significant effect on desire to leave. Therefore, the company should prevent the emergence of workplace bullying behavior, for example making ethical standards of work behavior. Rasool et al. (2013), stated that workplace bullying is more relevant to systematic weakness in the organization and less to employee performance while workplace bullying is more related to the personal characteristics of the victim, so regardless of their commitment, leaving the organization in such circumstances is a better alternative to victim.

\section{CONCLUSION}

The results of empirical studies in this study have shown that workplace bullying has a negative and significant effect on organizational commitment and has a positive and significant effect on turnover intention, organizational commitment has a negative and significant effect on turnover intention, and organizational commitment mediates the effect of workplace bullying on turnover intention. Based on these findings, the results of this study can be said to support the basic theory (grand theory) used in this study, namely the Social Exchange Theory, in which social exchange theory is identical to the exchange relationship between individuals comparing sacrifice and reward. obtained. The results of research at PT BPR NAGA show that the low level of workplace bullying affects the high level of employee organizational commitment which also affects the low level of turnover intention. This is in accordance with the social exchange theory which implies that if employees are treated well in the company, the employees will respond to positive behavior. Apart from this, the results of this study are also able to enrich knowledge in the field of Human Resource Management (HRM) and Organizational Behavior, as well as support other empirical studies related to the effect of workplace bullying and organizational commitment on turnover intention.

\section{REFERENCES}

Abdillah, F. 2012. Hubungan Kohevitas Kelompok Dengan Intensi Turnover pada karyawan. Journal of Social and Industrial Psychology. Vol. 1, No. 2, pp. 52-58.

Abdillah, W. dan Jogiyanto, H. M. 2009. Konsep Dan Aplikasi PLS (Partial Least Square) Untuk Penelitian Empiris. Yogyakarta : Badan Penerbit Fakultas Ekonomi Dan Bisnis Universitas Gadjah Mada.

Abelson, M.A. 1987. Examination of Avoidable and Unavoidable Examination. Journal of Applied Psychology, Vol. 72, pp. 382-386.

Adenguga, Adenuga, F. T., dan Ayodele, K. O. 2013. Organizational Commitment and Turnover Intention among Private Universities' Employees in Ogun State, Nigeria. Open Journal of 


\section{International Journal of Business Management and Economic Review}

Vol. 4, No. 03; 2021

ISSN: 2581-4664

Education, Vol. 1, No. 2, pp. 31-36.

Allen, N. dan Meyer, 1. PP. 1993. Organizational Commitment: Evidence of Career Stage Effects?. Journal of Business Research, Vol. 26, pp.. 49-61.

Aluedse, O. 2006. Bullying in School: A Form of Child Abuse in School. Journal Educational Research Quarterly. ProQuest Research Library. Ambrose Alli University.

Ameen, Elsie C., Jackson Cynthia, Pasewark William R., dan Strawser Jerry R. 1995. An Empirical Investigation of The Antecedents and Consequences of Job Insecurity on The Turnover Intentions of Academic Accountants. Issues in Accounting Educations. Vol.10. No.1. pp.65-82.

Andini, R. 2006. Analisis pengaruh kepuasan gaji, kepuasan kerja, komitmen organisasional terhadap turnover intention (studi kasus pada rumah sakit roemani muhammadiyah semarang). Tesis, Program Studi Magister Manajemen Universitas Diponogoro.

Astuti, P. R. 2008. Meredam Bullying: 3 Cara Efektif Mengatasi Kekerasan Pada Anak. Jakarta: Grasindo.

Aydogdu, Sinem dan Asikgil, Baris. 2011. An Empirical Study of the Relationship Among Job Satisfaction, Organizational Commitment, and Turnover Intention. International Review of Management and Marketing, Vol. 1, No.3, pp. 43-53.

Berthold, K. A., dan Hoover, J. H. 2000. Correlates of bullying and victimization among intermediate students in the midwestern USA. Journal of School Psychology Internatioal. Vol. 21, pp. 65-78.

Bhatti, M. H., Bhatti, M. H., Akram, U., Bilal, M., dan Akram, Z. 2016. Impact of Organization Commitment on Turnover Intention: Mediating Role of Job Contentment. European Journal of Business and Management. Vol.8, No.13, pp. 24-39

Blau, G. 2009. Can a four-dimensional model of occupational commitment help to explain intent to leave one's occupation?. Career Development International. Vol. 14 No. 2, pp. 116132

Blau, P. M. 1964. Exchange and power in social life. New York: Wiley.

Bohle P., Knox A., Noone J., Mc Namara M., Rafalski J, Michael Quinlan M. 2017. Work organisation, bullying and intention to leave in the hospitality industry. Employee Relations: The International Journal, Vol. 39 No. 4. Hal 1-19

Bunderson, JS. 2001. How Work Ideologies Shape the Psychological Contracts of Professional Employees: Doctor's Responses to Perceived Breach. Journal of Organizational Behavior, Vol. 22, No.7, pp. 717-741.

Chiu, C. K., Chien, C. H., Lin, C. P., dan Hsiao, C. Y. 2005. Understanding Hospital Employee Job Stress And Turnover Intentions In A Practical Setting The Moderating Role Of Locus Of Control. Journal of Management Development. Vol. 24, No. 10, pp. 837-855.

Cho, V., dan Huang, H. 2012. Professional commitment, organizational commitment, and the intention to leave for professional advancement: An empirical study on IT professionals. Information Technology \& People, Vol. 25 Iss: 1 pp. $31-54$.

Coetzee, M. dan Oosthuizen, R. M. 2017. Work-role psychosocial flourishing: Its mediation role on workplace bullying and employee turnover intention, Journal of Psychology in Africa. Vol. 27 No. 3,pp 211-215

Coetzee, M. dan Dyk J. 2017. Workplace Bullying and Turnover Intention: Exploring Work Engagement as a Potential Mediator. Psychological Report. Vol 0,pp 1-18 
Coloroso, B. 2007. Stop Bullying. Jakarta: Serambi Ilmu Pustaka

Craig, W., Pepler, D., dan Blais, J. 2007. Responding to perundungan, what works?. School Psychology International, Vol. 28, pp 465-477.

Cropanzano, R., Prehar, C., A. \& Chen, P., Y. 2002. Using social exchange theory to distinguish procedural from interactional justice. Group organization management. Vol. 27, No. 3, pp. 324-351.

Dalton, D.R, \& Todor, W.D. 1993. Turnover, transfer, and absenteeism: An interdependent perspective. Journal of Management. Vol. 19, pp. 193-219.

Djamilah, S., Julindrastuti, D., dan Karyadi, I. 2012. Pengaruh Bullying di Tempat Kerja Terhadap Keinginan Keluar : Efek Mediasi Komitmen Organisasi Afektif. Equilibrium. Vol. 10, No. 2, pp. 97-115.

Dumitru, A. R., Burtaverde, V., dan Mihaila, T. 2015. Exploring Turnover, Bullying At Work And Organizational Commitment In The Communication Field. Romanian Journal Of Experimental Applied Psychology. Vol. 6, No. 4, Pp. 65-78

Durkin, M. 1999. Employee Commitment in Retail Banking: Identifying and Exploring Hidden Dangers. International Journal of Bank Marketing. Vol. 17, No. 3, pp. 124-134

Einarsen, S. 1999. The nature and causes of bullying at work. International Journal of Manpower, Vol 20. Pp 16-27.

Einarsen, S. dan Skogstad, A. 1996. Bullying at work: Epidemiological findings in public and private organizations. European Journal of Work and Organizational Psychology, Vol 5, pp 185-201.

Einarsen, S., Hoel, H., dan Notelaers, G. 2009. Measuring exposure to bullying and harassment at work: Validity, factor structure and psychometric properties of the Negative Acts Questionnaire-Revised. Work \& Stress. Vol. 23, No. 1, pp. 24-44

Einarsen, S., Hoel, H., Zapf, D. dan Cooper, C. L. 2003. The concept of bullying at work: The European tradition. International Perspectives in Research and Practice (pp. 3-30). London: Taylor and Francis

Emerson, R., M. 1976. Social exchange theory. Annual review of sociology. Vol. 2, pp. 335-362.

Erat, S., Kitapci, H., dan Comez, P. 2017. The Effect Of Organizational Loads On Work Stress, Emotional Commitment, And Turnover Intention. International Journal of Organizational Leadership. Vol 6, No. 2, pp. 221-231.

Faslah, R. 2010. Hubungan antara Keterlibatan Kerja dengan Turnover Intention pada Karyawan PT. Garda Trimitra Utama, Jakarta. EconoSains. Vol. 8, No. 2, pp. 146-151.

Ghosh, P., Satyawadi, R., Joshi, J. P., Shadman, M. 2013. Who stays with you? Factors predicting employees' intention to stay. International Journal of Organizational Analysis. Vol. 21 No. 3, 2013 pp. 288-312.

Ghozali, I. 2006. Aplikasi Analisis Multivariate Dengan Program SPSS. Cetakan Keempat. Semarang: Badan Penerbit Universitas Diponegoro

Ghozali, I. 2014. Structural Equation Modeling, Metode Alternatif dengan Partial Least Square (PLS). Edisi 4. Semarang : Badan Penerbit Universitas Diponegoro.

Glambek, M., Matthiesen S. B., Hetland, J., dan Einarsen, S. 2014. Workplace bullying as an antecedent to job insecurity and intention to leave: a 6-month prospective study. Human Resource Management Journal. Vol. 24. No. 3. pp 255-268 


\section{International Journal of Business Management and Economic Review}

Vol. 4, No. 03; 2021

ISSN: 2581-4664

Gunawan, A., dan Ulfa'i, U. 2018. Pengaruh Stress Kerja Terhadap Turnover Intention Dengan Kepuasan Kerja Sebagai Variabel Intervening (Studi Pada Bagian Account Officer BPR Cirebon). Jurnal Manajemen dan Akuntansi. Vol. 13, No.1, pp. 14-34.

Hakim, A. L., Sudarmiatin, dan Sutrisno. 2018. The Effect of Work Stress on Turnover Intention with Work Satisfaction and Commitment as Intervening Variable (Study at PT Infomedia Solusi Humanika in Malang). European Journal of Business and Management. Vol.10, No.12, pp. 85-94.

Handoko, T. H. 2014. Manajemen personalia dan sumber daya manusia. Yogyakarta : BPFE.

Harnoto, 2002. Manajemen Sumber Daya Manusia. Edisi Kedua. PT. Prehallindo, Jakarta Harnoto. 2002. Manajemen Sumber Daya Manusia. Edisi Kedua. Jakarta: PT. Prehallindo Harvey, P., Stoner, J., Hochwarter, W., \& Kacmar, C. 2007. Coping with abusive supervision: The neutralizing effects of ingratiation and positive affect on negative employee outcomes. Leadership Quarterly. Vol. 18, pp. 265-280.

Hasibuan, M. S. P. 2017. Manajemen Sumber Daya Manusia. Edisi Revisi. Jakarta : Bumi Aksara

Hernández, E.; Millán, L. V.; Et al. 2018. Effect of the Exposure to Workplace Bullying on Turnover Intention and The Mediating Role of Job Satisfaction, Work Engagement, and Burnout. Revista Interamericana de Psicología Ocupacional. Vol. 37, No. 1, pp. $26-51$

Hernandez, R., E., Rovira Millán, L. V.; Et al. 2018. Effect of the Exposure to Workplace Bullying on Turnover Intention and The Mediating Role of Job Satisfaction, Work Engagement, and Burnout. Revista Interamericana de Psicología Ocupacional. Vol. 37, No. 1 , pp. $26-51$

Hoel, H. dan Cooper, C. 2000. Destructive conflict and bullying at work. Unpublished Report,UK: University of Manchester Institute of Science and Technology.

Jaros, SJ; Jermier, J, Koehler, J, dan Sincich, T. 1993. Effects of Continuance, Affective, and Moral Commitment on the Withdrawal Process: an Evaluation of Eight Structural Equation Models. Academy of Management Journal, Vol 36, No.5, pp. 951-959.

Jawapos. 2017. Pertumbuhan BPR Melambat, Kredit Macet Naik Hingga 47 Persen. Online. (https://www.jawapos.com/radarbali/read/2017/08/24/ 9378/pertumbuhan-bpr-melambatkredit-macet-naik-hingga-47-persen, di akses tanggal 12 Desember 2017)

Jehanzeb, K., Rasheed, A., dan Rasheed, M. F. 2013. Organizational Commitment and Turnover Intentions: Impact of Employee's Training in Private Sector of Saudi Arabia. International Journal of Business and Management. Vol. 8, No. 8, pp. 79-90

Jha, S. 2010. Influence of Psychological Empowerment on Affective, Normative and Continuence. Journal of Business Studies Quarterly, Vol. 3, No. 4, pp. 263-284.

John, M.C. dan Taylor, J.W. 1999. Leadership Style, School Climate, and the Institutional Commitment of Teachers. International Forum, Vol.2, No. 1, pp. 25-57.

Kaushalya, S. A. H., dan Alwis, C. D. 2016. The Moderating Effects on The Relationships Between Workplace Bullying and Intention to Leave. Kelaniya Journal of Human Resource Management. Vol. 11, No. 02, pp. 110-127

Krahe, B. 2005. Perilaku Agresif: Buku Panduan Psikologi Sosial. Yogyakarta: Pustaka Pelajar Labrague, L. J., Petitte, D. M., Tsaras, K., Cruz, J. P., Colet, P. C., dan Gloe, D. S. 2018. Organizational commitment and turnover intention among rural nurses in the Philippines: 


\section{International Journal of Business Management and Economic Review}

Vol. 4, No. 03; 2021

ISSN: 2581-4664

Implications for nursing management. International Journal of Nursing Sciences. Vol. 5, pp. 403-408

Lawler, E., J. 2001. An affect theory of social exchange. American journal of sociology. Vol.107, No. 2, pp. 321-352.

Lawler, E., J., dan Thye, S., R. 1999. Bringing emotion into social exchange theory. Annual review of sociology. Vol. 25, pp. 217-244.

Lawler, E., J., Thye, S., R. \& Yoon, J. 2008. Social exchange and micro social order. American sociological review. Vol. 73, No. 4, pp. 519-542.

Luz, C. M. D. R., Paula, S, L., dan Barbosa, L. M. 2018. Organizational commitment, job satisfaction and their possible influences on intent to turnover. Revista de Gestão. Vol. 25 No. 1, pp. 84-101

Malhotra, N. K. 2009. Riset Pemasaran Pendekatan Terapan, Edisi keempat, Jilid 1. Jakarta : PT Indeks.

Malik, Muhammad Shaukat; Sattar, Shahzadi; Yaqub, Rana Muhammad Shahid (2018): Mediating role of psychological contract breach between workplace bullying, organizational commitment \& employee turnover intentions, Pakistan Journal of Commerce and Social Sciences (PJCSS), ISSN 2309-8619, Johar Education Society, Pakistan (JESPK), Lahore, Vol. 12, Iss. 3, pp. 935-952

McCormack, D., Casimir, G., Djurkovic, N., dan Yang, L. 2009. Workplace Bullying and Intention to Leave Among Schoolteachers in China: The Mediating Effect of Affective Commitment. Journal of Applied Social Psychology, Vol 39, No 9, pp. 2106-2127

Mete, E. S., Sökmen, A. 2016. The Influence of Workplace Bullying on Employee's Job Performance, Job Satisfaction and Turnover Intention in a Newly Established Private Hospital. International Review of Management and Business Research Vol. 05, No.01.pp 65-79.

Miner, J. B. 1992. Industrial Organizational Psychology. New York: The State University of New York at Buffalo.

Mitchell, M. S., Cropanzano, R. S., \& Quisenberry, D. M. 2012. Social exchange theory, exchange resources, and interpersonal relationships: A modest resolution of theoretical difficulties. In Handbook of social resource theory (pp. 99-118). Springer New York.

Narwin, R. 2016. Social Exchange Theory in Human Resource Development Context. St. Theresa Journal of Humanities and Social Sciences. Vol. 2, No. 2, pp. 74-78.

Norris, D. R., dan Neibuhr, R. E. 1993. Profesionalism, Organizational Commitment and Job Satisfaction in an Accounting Organization, Accounting, Organization and Society.Vol 1, pp. 49-60.

Nwobia, I. E., dan Aljohani, M. S. 2017. The Effect of Job Dissatisfaction and Workplace Bullying on Turnover Intention: Organization Climate and Group Cohesion as Moderators. International Journal of Marketing Studies. Vol. 9, No. 3. pp 136-143.

Olweus, D. 2006. Olweus Bullying Questionnaire. Center City, MN: Hazelden.

Paaisal, L. O. R., Tabroni, dan Maksum, C. 2018. Pengaruh Gaya Kepemimpinan Dan Budaya Organisasi Terhadap Turnover melalui Kepuasan Kerja Karyawan Pada Pt. Muara Wisesa Samudra Di Jakarta. Jurnal Eksekutif. Vol. 15, No. 1, pp. 191-215.

Park, H. Y., Christie, R. L., dan Sype, G. E. 2014. Organizational Commitment and Turnover Intention in Union and Non-Union Firms. SAGE Open. pp. 1-11 
Vol. 4, No. 03; 2021

ISSN: 2581-4664

Park, M. S., Oh, C. U., dan Han, H. S. 2018. Influences of The Workplace Bullying and Social Support on Turnver Intention of Nurse. Journal of the Korea Academia-Industrial Cooperation Society. Vol. 19, No. 9, pp. 166-173

Parvaiz, L., Batool, S., Khalid, A., dan Aftabfarooqi, Y. 2015. Impact of Stressors (Role conflict, Role overload, Leadership Support and Organizational Politics) on Job Stress and its subsequent impact on Turnover Intention. International Journal of Business and Management Invention. Vol. 4, No. 10, pp. 52-63.

Pasewark, W. R., dan J. R. Strawser. 1996. The Determinants and Outcomes Associated with Job Insecurity in a Professional Accounting Environment. Behavioral Research in Accounting. Vol 8, pp 91-113.

Putra, D. K., dan Pujiastuti, I. S. 2015. Pengaruh Workplace Bullying Pada Kepuasan Kerja, Komitmen Organisasi, Dan Niat Untuk Berpindah Dengan Strain Sebagai Variabel Mediasi. Fokus Manajerial.Vol. 13 No. 2 pp. 177-188

Rasool, F., Arzu, F., Hasan, A., Rafi, A., dan Rauf, A. 2013. Workplace Bullying and Intention to Leave: The Moderating Effect of the Organizational Commitment. Information Management and Business Review. Vol. 5, No. 4, pp. 175-180

Razzaghian, M. dan Ghani, U. 2014. Effect of Workplace Bullying on Turnover Intention of Faculty Members: A Case of Private Sector Universities of Khyber Pakhtunkhwa, Pakistan. Business \& Economic Review: Vol. 6, No. 1, pp. 40-51.

Rigby, K. 2002. New Perspectives on Bullying. London : Jessica Kingsley

Robbins, S. P. 2015. Perilaku Organisasi (Organizational Behavior) Jilid 2. Jakarta : Salemba Empat.

Robbins, S. P., dan Judge, T. A. 2015. Perilaku Organisasi. Jakarta: Salemba Empat.

Rodly, I. A. 2012. Turnover Karyawan Kajian Literatur. Online. (https://www.scribd.com/doc/78478535/Turn-Over-Karyawan-Kajian-Literatur, di akses tanggal 12 Desember 2017)

Saklit, I. W. 2017. Pengaruh Gaya Kepemimpinan Dan Pengembangan Karir Terhadap Intensi Turnover: Kepuasan Kerja Sebagai Mediator. Jurnal Manajemen. Vol. 21, No. 03, pp. 472-490.

Salin, D., dan Notelaers, G. 2017. The Effect Of Exposure To Bullying On Turnover Intentions: The Role Of Perceived Psychological Contract Violation And Benevolent Behavior. Work \& Stress. pp. 1-21.

Sartika, D. 2014. Pengaruh Kepuasan Kerja Dan Gaya Kepemimpinan Transformasional Terhadap Keinginan Keluar Karyawan Dengan Komitmen Organisasi Sebagai Variabel Mediasi(Studi Kasus Di Cv. Putra Tama Jaya). Management Analysis Journal. Vol. 3, No. 2, Pp 1-11.

Shobirin, M., Minarsih, M. M., dan Fathoni, A. 2016. Analisis Pengaruh Kepemimpinan, Komitmen Organisasi Dan Kepuasan Kerja Terhadap Keinginan Pindah Kerja Karyawan Pt. Pt. Bank Btpn Mitra Usaha Rakyat Area Semarang. Journal of Management. Vol.02, No.02, pp.1-18.

Sim, R. L., dan Sun, P. 2012. Witnessing workplace bullying and the Chinese manufacturing employee. Journal of Managerial Psychology. Vol. 27 No. 1, pp. 9-26 


\section{International Journal of Business Management and Economic Review}

Vol. 4, No. 03; 2021

ISSN: 2581-4664

Sintaasih, D. K., Dewi, I. G. A. M., Utama, I. W. M., dan Mujiati, N. W. 2017. Work spirituality Its effect to the organizational commitment and performance of rural credit institution administrator. International Journal of Ethics and Systems. Vol. 35 No. 3, pp. 306-322

Steers, R.M., dan Porter, L.W., 1987. Motivation and Work Behavior. USA: McGraw-Hill inc.

Stein, J. A., Dukes, R. L. \& Warren, J. I. (2006). Adolescent Male Bullies, Victims, and BullyVictims: A Comparison of Psychosocial and Behavioral Characteristics. Journal of Pediatric Psychology. Vol. 32, No. 3, pp. 273-282.

Sgiono. 2013. Metode Penelitian Bisnis. Cetakan ke-17. Bandung: Alfabeta.

Sugiyono. 2017. Metode Penelitian Kuantitatif, Kualitatif, dan R\&D. Bandung : Alfabeta.

Swearer, M. Susan dkk. 2010. What Can Be Done About School Bullying? Linking Research to Educational Practice. Jurnal Educational Researcher Vol. 39, No. 1, pp. 38-47

Tepper, B. J., Duffy, M. K., Hoobler, J. M., \& Ensley, M. D. 2004. Moderators of the relationship between coworkers' organizational citizenship behavior and fellow employees' attitudes. Journal of Applied Psychology. Vol. 89, pp. 455-465.

Thibaut, J. W., and Kelley, H. H. 1959. The Social Psychology of Groups. New York: John Wesley \& Sons.

Tnay E, Othman A. E. A, Siong H. C, Lim S. L. O. 2013. The Influence of Job Satisfaction and Organizational Commitment on Turnover Commitment. Elsevier Procedia-Social and Behavioral Sciences, Vol 1. No 97, Hal. 201-208.

Widyadmono, V. M. 2015. Pengaruh Kepuasan Kerja Dan Komitmen Organisasi Terhadap Turnover Intention (Studi Pada Accounting Staff Perusahaan Swasta Di Diy). Jurnal Manajemen Indonesia. Vol. 15. No.2, Pp 157-168

Yang, J., Pu, B., dan Guan, Z. 2019. Entrepreneurial Leadership And Turnover Intention In Startups: Mediating Roles Of Employees' Job Embeddedness, Job Satisfaction And Affective Commitment. Sustainability. Vol. 11, pp. 1-15.

Yuksel, M., dan Tuncsiper, B. 2011. The Relationship Between Mobbing and Organizational Commitment in Workplace. International Review of Management and Marketing. Vol. 1, No. 3, pp. 54-64

Yuliasia, Yeni., Imam Santoso., dan Arif Hidayat. 2012. Analisis Variabel Yang Mempengaruhi Keinginan Berpindah (Turnover Intention) dengan Structural Equation Modeling (Sem) (Studi Kasus PT Wonokoyo Jaya Corporindo,Pasuruan). Jurnal Teknologi Pertanian. Vol. 13, No. 1, pp. 61-66.

Zhou X., Lynch Jr, J.G., Chen Q., 2010. Reconsidering Baron and Kenny : Myths and Truths about Mediation Analysis. Journal of Consumer Research. Vol 37, pp. 197-206. 